\title{
Validation of a new fiber electrode prototype for clinical electroretinography
}

\author{
Validação de protótipo de um novo eletrodo de fibra \\ para eletrorretinografia clínica
}

\author{
Adriana Berezovsky ${ }^{1}$ \\ Josenilson Martins Pereira ${ }^{2}$ \\ Solange Rios Salomão ${ }^{3}$ \\ Vagner Rogério dos Santos ${ }^{4}$ \\ PauloSchor ${ }^{5}$
}

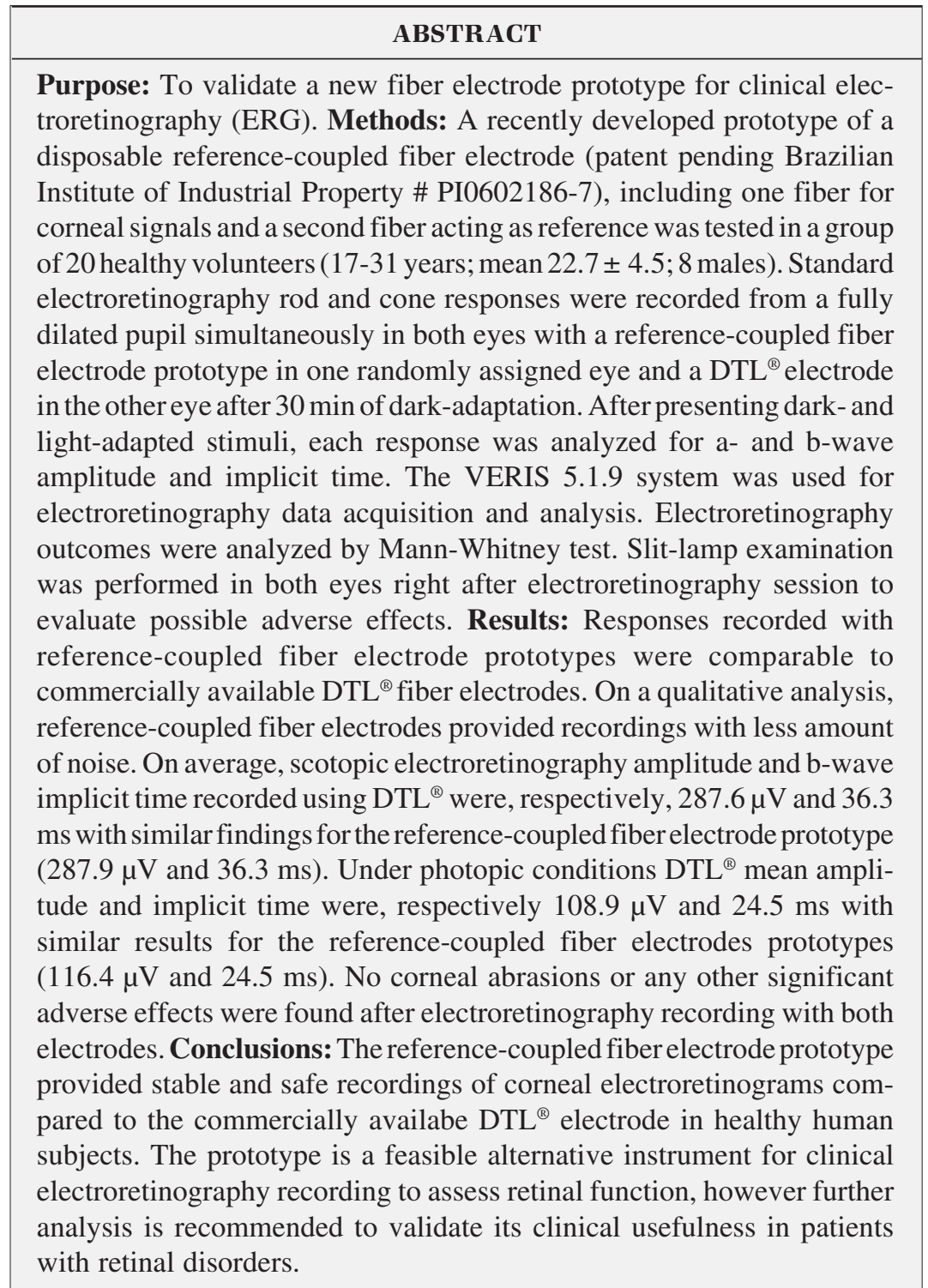

Keywords: Electrodes; Electroretinography/instrumentation; Retina/physiology; Retinal diseases; Validation studies
Trabalho realizado no Departamento de Oftalmologia da Universidade Federal de São Paulo - UNIFESP - São Paulo (SP) - Brasil.

Doutora em Ciências e Professora Adjunto do Departamento de Oftalmologia da Universidade Federal de São Paulo - UNIFESP - São Paulo (SP) - Brasil.

2 Tecnólogo Oftálmico do Setor de Eletrofisiologia Visual Clínica e Mestre em Ciências Visuais do Departamento de Oftalmologia da UNIFESP - São Paulo (SP) Brasil.

Professora Associada, Livre Docente e Chefe do Setor de Eletrofisiologia Visual Clinica pelo Departamento de Oftalmologia da UNIFESP - São Paulo (SP) - Brasil. Tecnólogo em mecânica de precisão pela Faculdade de Tecnologia de São Paulo - FATEC-SP - São Paulo (SP) - Brasil e Preceptor do Curso de Tecnologia Oftálmica da UNIFESP - São Paulo (SP) - Brasil.

Professor Livre Docente e Chefe do Setor de Bioengenharia do Departamento de Oftalmologia da UNIFESP São Paulo (SP) - Brasil.

Endereço para correspondência: Adriana Berezovsky. Departamento de Oftalmologia - UNIFESP. Rua Botucatu, 822 - São Paulo (SP) CEP 04023-062

E-mail: aberezovsky@oftalmo.epm.br

Recebido para publicação em 02.07.2007

Última versão recebida em 04.09.2007

Aprovação em 21.09.2007 


\section{INTRODUCTION}

Full-field electroretinography is widely used in the diagnosis and clinical monitoring of several retinal conditions including inherited eye diseases, retinotoxic effects of systemic drugs and to evaluate treatment protocols. The full-field electroretinogram (ERG) represents the summed activity of the distal retina in response to light flashes and this electrical response is recorded by several types of electrodes ${ }^{(1-4)}$.

Since recording the first human ERG over a century ago, numerous electrodes have been developed in search of an ideal electrode that would accurately record the ERG and still be comfortable for the patient ${ }^{(5)}$. Corneal contact lens electrodes are considered optimal for recording human full-field flash ERGs since they yield large amplitude and high signal-tonoise ratio $^{(6)}$. Unfortunately these electrodes have unwanted side effects. The most usual side effects frequently seen by ERG specialists are corneal abrasions, inability to fit small palpebral fissures (pediatric ERGs) and the need of cooperation from the subjects ${ }^{(6)}$. Besides these disadvantages are the rising cost of these electrodes and the increasing difficulty in getting a regular supply, especially on short notice (usually they are handmade) in developing countries. Finally, the deterioration of the optical quality of the eye, caused by contact lens, prevents its use for pattern ERG studies ${ }^{(6-7)}$.

For such reasons, some investigators have chosen electrodes such as the DTL ${ }^{\circledR}$ fiber electrode ${ }^{(7)}$, which is less invasive, does not require anesthesia of the eye, and can be used for lengthy recording periods ${ }^{(8)}$. The stability and reproducibility of ERG responses recorded by DTL ${ }^{\circledR}$ electrodes have been tested and the results were favorable in both aspects ${ }^{(8)}$.

Bipolar contact lens electrodes are recommended by the International Society for Clinical Electrophysiology of Vision (ISCEV) since they promote more stable and noiseless ERG recordings. However, commercially available fiber electrodes are monopolar, requiring a second electrode placed in the external canthus to act as a reference pole. A fiber electrode with the reference terminal coupled would be highly useful since it would have both terminals attached to the same place.

In developing countries as Brazil, both contact lens and disposable fiber electrodes for ERG recording are not locally manufactured, requiring importation at high cost. The purpose of this study is to validate a recently developed reference-coupled fiber electrode prototype for clinical electroretinography. Its validation includes investigation of its efficacy compared to commercially available monopolar DTL ${ }^{\circledR}$ electrodes for each parameter of the ERG.

\section{METHODS}

\section{Subjects}

This study has been approved by the Committee of Ethics in Research of the Federal University of São Paulo and has followed the tenets of the Declaration of Helsinki. A group of
20 healthy volunteers (17-31 years; mean $22.7 \pm 4.5 ; 8$ males) was recruited for the study. The inclusion criteria were: best corrected visual acuity for distance equal or better than 0.0 $\log$ MAR (20/20), absence of visual complaints, normal fundus, and compliance with the informed consent form. Exclusion criteria were: history of hereditary eye diseases, history of previous ocular surgeries or high ametropia (myopia $=-5.00$ spherical equivalent, hyperopia $=+5.00$ spherical equivalent).

\section{Reference-coupled disposable fiber electrodes}

Full-field ERG was recorded through a recently developed disposable reference-coupled fiber electrode prototype (patent pending Brazilian Institute of Industrial Property \# PI0602186-7). The prototype is composed of nylon monofilament $6 \mathrm{~cm}$ long $100 \mu \mathrm{m}$ thick impregnated with metallic silver (for corneal signals) and a second fiber with the same parameters serving as reference. At both ends small sponges $(1.0 \mathrm{~cm} \times 1.0 \mathrm{~cm})$ are secured to internal and external canthi by means of double-sided adhesive tape and conductive adhesive. The active electrode was positioned in the lower conjunctival sac and at the same time the reference was positioned beside the external canthus (Figure 1).

\section{Full field electroretinography}

ERG was simultaneously recorded from both eyes: one randomly assigned eye with the reference-coupled fiber electrode prototype and the fellow eye with monopolar DTL ${ }^{\circledR}$ (Diagnosys LLC, Lowell, MA, USA). All ISCEV rod and cone responses were obtained from a fully dilated pupil after 30 min of dark-adaptation ${ }^{(2)}$. The VERIS 5.1.9 (Electro-Diagnostic Imaging, San Mateo, California, USA) system was used for ERG data acquisition and analysis. Stimulus and recording parameters are defined in table 1. After 30 minutes of dark adaptation, ERG responses were recorded in the following order: (a) a maximal intensity white light attenuated by a 2.4 $\log$ neutral density filter to elicit a dark-adapted rod response; (b) a maximal intensity white light to elicit a mixed darkadapted rod and cone response; (c) the maximal intensity white light with a $100-\mathrm{Hz}$ low-cut and $1-\mathrm{KHz}$ high-cut filter to elicit oscillatory potentials; and the maximal intensity white light on a $30 \mathrm{~cd} / \mathrm{m}^{2}$ background presented; at (d) $1 \mathrm{~Hz}$ and (e) $30 \mathrm{~Hz}$ to elicit cone responses. A period of $10 \mathrm{~min}$ was allowed to adapt to the background light when collecting the cone responses. Twenty responses were computer-averaged for each step of the standard protocol, except for the $30-\mathrm{Hz}$ flicker for which 50 responses were averaged. After presenting standard dark- and light-adapted stimuli, each response was analyzed for a- and b-wave amplitude and implicit time. Slit-lamp examination was performed in both eyes right after ERG session to evaluate possible adverse effects.

\section{Statistical analysis}

Data from ERG parameters (peak-to-peak amplitude and implicit time) from each step of the ISCEV standard protocol were compared between the reference coupled fiber electrode 

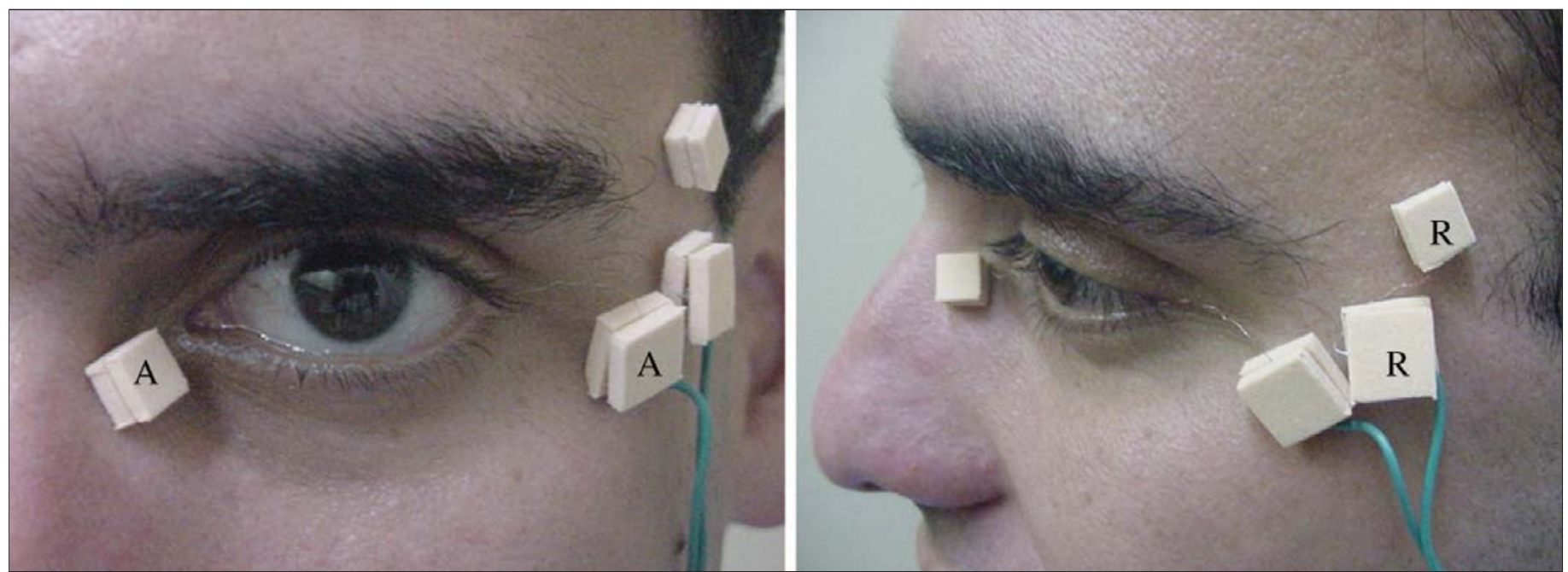

Figure 1 - Fitting of the fiber electrodes with reference coupled prototype for ERG recording. Active electrode is secured to both canthi and placed at the lower conjunctival sac, while the reference electrode is secured at the side. $(A)$ active electrode. $(R)$ reference electrode.

\begin{tabular}{|c|c|c|c|c|c|c|}
\hline $\begin{array}{l}\text { Response } \\
\mathrm{N} \text { (number of trials) }\end{array}$ & 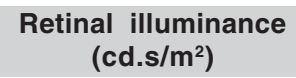 & Frequency & $\begin{array}{l}\text { of presentation } \\
(\mathrm{Hz})\end{array}$ & $\begin{array}{l}\text { Background } \\
\left(\mathrm{cd} . / \mathrm{m}^{2}\right)\end{array}$ & $\begin{array}{c}\text { Low-cut } \\
(\mathrm{Hz})\end{array}$ & $\begin{array}{l}\text { Hi-cut } \\
\text { (KHz) }\end{array}$ \\
\hline $\begin{array}{l}\text { Rod-isolated } \\
20\end{array}$ & 0.0084 & & 1 & none & 1 & 1 \\
\hline $\begin{array}{l}\text { Maximal } \\
10\end{array}$ & 2.5067 & & 1 & none & 1 & 1 \\
\hline $\begin{array}{l}\text { Oscillatory potentials } \\
20\end{array}$ & 2.5067 & & 1 & none & 100 & 1 \\
\hline $\begin{array}{l}\text { Single-flash cone } \\
20\end{array}$ & 2.4851 & & 1 & 30.06 & 1 & 1 \\
\hline $\begin{array}{l}\text { Flicker } \\
50\end{array}$ & 2.5021 & & 30 & 30.82 & 10 & 1 \\
\hline
\end{tabular}

prototype and the DTL ${ }^{\circledR}$ electrode by the Mann-Whitney rank sum test.

\section{RESULTS}

Responses recorded with reference-coupled fiber electrode prototypes were comparable to DTL ${ }^{\circledR}$ electrodes. On a qualitative analysis, the fiber electrodes with reference-coupled showed less amount of electrical noise (Figure 2).

Mean b amplitudes (measured peak-to-peak from a wave to $b$ wave) and respective standard deviations for rod, maximal response, cone, flicker responses (average of sinusoidal peak-to-peak responses) and oscillatory potentials (OP2) obtained from both electrodes are plotted in figure 3 and shown in table 2. Mean b implicit times and respective standard deviations for rod, maximal response, cone, flicker responses obtained from both Groups are plotted in figure 4 and shown in table 2.

On average, scotopic ERG amplitude and b-wave implicit time recorded using $\mathrm{DTL}^{\circledR}$ were, respectively, $287.6 \mu \mathrm{V}$ and
$36.3 \mathrm{~ms}$ while with reference-coupled fiber electrode prototype the same parameters were, respectively, $287.9 \mu \mathrm{V}$ and $36.3 \mathrm{~ms}$. Under photopic conditions DTL ${ }^{\circledR}$ mean amplitude and implicit time were, respectively $108.9 \mu \mathrm{V}$ and $24.5 \mathrm{~ms}$ while with reference-coupled fiber electrode prototype they were respectively $116.4 \mu \mathrm{V}$ and $24.5 \mathrm{~ms}$. No corneal abrasions were found after ERG recording with both types of electrodes. Rod, maximal, and cone $30-\mathrm{Hz}$ flicker responses showed similar waveforms and parameters for both electrodes.

\section{DISCUSSION}

In the present study, the recently developed referencecoupled fiber electrode prototype provided ERG responses similar to those recorded with the commercially available DTL $^{\circledR}$ electrode. No statistical differences were found in ERGs obtained by the two electrodes for all parameters studied. The prototype is more affordable locally and provides stable and safe recordings of corneal electroretinograms compared to the gold standard DTL ${ }^{\circledR}$ electrode. 


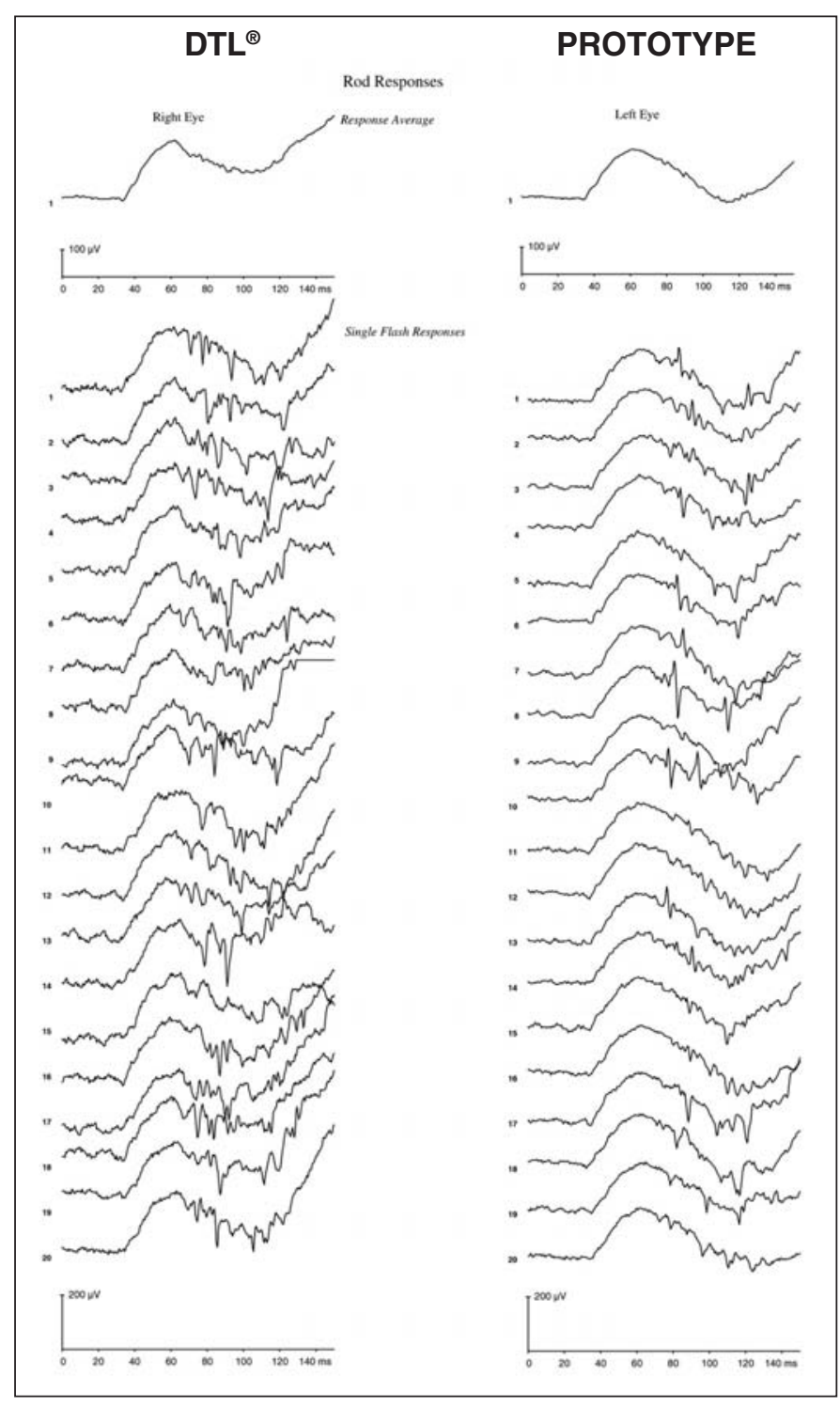

Figure 2 - Representative rod responses from a healthy volunteer. In the left panel ERG recording obtained with $\mathrm{DTL}^{\circledR}$ electrode; in the right panel ERG recorded with the new reference-coupled fiber electrode prototype.

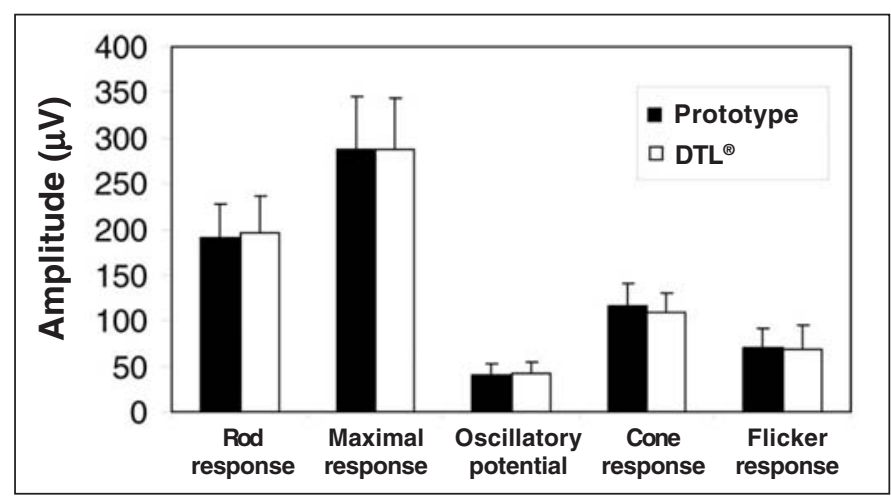

Figure 3 - Mean b-wave ERG amplitudes (measured peak-to-peak from a-wave to b-wave) and respective standard deviation for rod response, maximal response, oscillatory potentials, cone response and $30-\mathrm{Hz}$ flicker from the new reference-coupled fiber electrode prototypes and $\mathrm{DTL}^{\circledR}$ electrodes

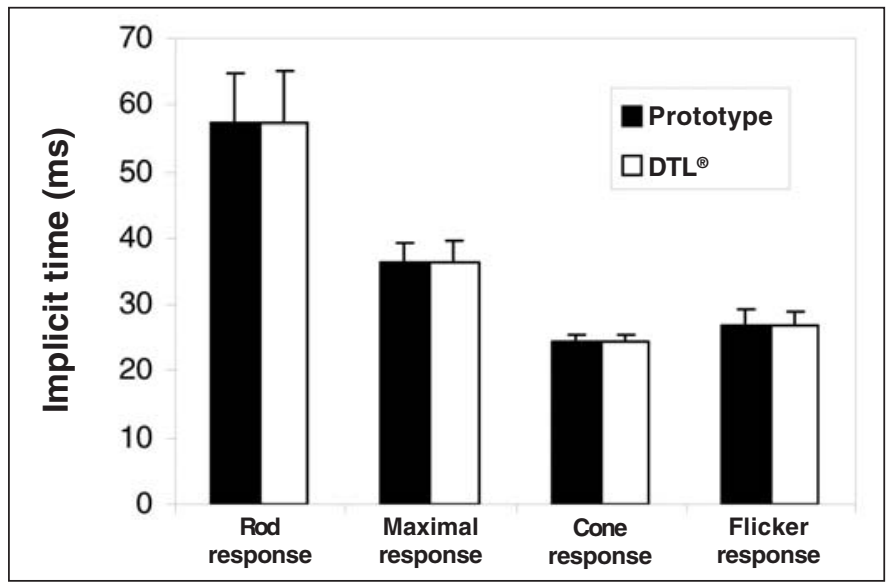

Figure 4 - Mean b-wave ERG implicit time and respective standard deviation for rod response, maximal response, cone response and $30-\mathrm{Hz}$ flicker from the new reference-coupled fiber electrode prototype and $\mathrm{DTL}^{\circledR}$ electrodes

\begin{tabular}{|c|c|c|c|}
\hline & \multicolumn{2}{|c|}{$\begin{array}{c}\text { Mean and respective } \\
\text { standard deviation }\end{array}$} & \\
\hline & Bipolar prototype & $\mathrm{DTL}^{\circledR}$ & \\
\hline \multicolumn{4}{|l|}{ Amplitude $(\mu \mathrm{V})$} \\
\hline Rod & $191.1(36.2)$ & $195.7(40.7)$ & $p=0.835$ \\
\hline Maximal response & $287.9(58.05)$ & $287.6(56.4)$ & $p=0.874$ \\
\hline Oscillatory potentials & $40.4(11.7)$ & $42.5(11.4)$ & $p=0.783$ \\
\hline Cone response & $116.4(24.9)$ & $108.9(20.8)$ & $p=0.330$ \\
\hline Flicker response & $69.8(22.2)$ & $68.5(26.2)$ & $p=0.845$ \\
\hline \multicolumn{4}{|l|}{ Implicit time } \\
\hline Rod & $57.4(7.5)$ & $57.3(7.60)$ & $p=0.764$ \\
\hline Maximal response & 36.3 (3.3) & $36.3(3.11)$ & $p=0.812$ \\
\hline Cone response & $24.5(1.0)$ & $24.5(0.90)$ & $p=0.733$ \\
\hline Flicker response & 26.7 (2.4) & $26.9(2.40)$ & $p=0.393$ \\
\hline
\end{tabular}

Many kinds of electrodes have been patented. When compared with contact lens electrode, the fiber electrode is better tolerated by children because it is less traumatizing and does not require anesthetic eye drops. Several studies showed high stability for DTL ${ }^{\circledR}$ as the conventional contact lens electro$\mathrm{des}^{(8-10)}$. The present study indicated that a quantitative measurement of fiber electrodes with reference coupled prototype is adequate for diagnostic purposes and for standard ERG recordings. Eye movements and electrode type can affect the quality of ERG recordings. To maximize recording stability, the reference-coupled fiber electrode prototype should be loosely placed in the conjunctival sac. This new fiber electrode minimized the risk of corneal abrasion and seems to be a good alternative for developing countries.

\section{CONCLUSION}

In summary, our findings clearly indicate that the reference-coupled fiber electrode prototype is adequate for ERG 
recording in healthy humans. It presented lower cost, easiness of use and provided comfort to the subject. Finally, further studies using this new electrode in retinal disease patients are needed to analyze the clinical usefulness and to extend the clinical validation of this new instrument.

\section{RESUMO}

Objetivo: Validar um novo protótipo de um eletrodo de fibra para eletrorretinografia clínica (ERG). Métodos: Foi testado em um grupo de 20 voluntários saudáveis (17-31 anos; média $22,7 \pm 4,5 ; 8$ homens), um protótipo de eletrodo de fibra com referência acoplado descartável recentemente desenvolvido (depósito de patente no Instituto Nacional de Propriedade Intelectual \# PI0602186-7), constando de uma fibra de sinais corneanos e uma segunda fibra servindo como referência. Após 30 minutos de adaptação ao escuro, as respostas de cones e bastonetes da eletrorretinografia foram registradas simultaneamente com dilatação completa das pupilas em ambos os olhos, com o protótipo de eletrodo de fibra com referência acoplado em um olho escolhido ao acaso e um eletrodo DTL ${ }^{\circledR}$ no outro olho. Após a apresentação dos estímulos escotópicos e fotópicos cada resposta foi analisada em amplitude e tempo de culminação das ondas a e b. O sistema VERIS 5.1.9 foi usado para a aquisição e análise dos dados. Os resultados da eletrorretinografia foram analisados pelo teste de Mann-Whitney. Após a sessão da eletrorretinografia foi feito exame em lâmpada de fenda para avaliar possíveis eventos adversos. Resultados: As respostas obtidas com o protótipo de eletrodo de fibra com referência acoplado foram comparáveis às do eletrodo DTL ${ }^{\circledR}$ comercialmente disponível. Numa análise qualitativa, o eletrodo de fibra com referência acoplado produziu sinais com menos ruído. Na média, a amplitude escotópica da eletrorretinografia e o tempo de culminação da onda-b usando o eletrodo DTL ${ }^{\circledR}$ foram respectivamente, 287,6 $\mu \mathrm{V}$ and 36,3 $\mathrm{ms}$ com achados similares para o protótipo $(287,9 \mu \mathrm{V}$ e $36,3 \mathrm{~ms})$. Sob condições fotópicas, a amplitude média do eletrodo DTL ${ }^{\circledR}$ e o tempo de culminação da onda $b$ foram respectivamente $108,9 \mu \mathrm{V}$ e $24,5 \mathrm{~ms}$ com resultados similares para o protótipo $(116,4 \mu \mathrm{V}$ e $24,5 \mathrm{~ms})$. Após os registros da eletrorretinografia com ambos os tipos de eletrodos não houve abrasões corneanas ou outros eventos adversos significantes. Conclusões: Em sujeitos humanos saudáveis, o protótipo de eletrodo de fibra com referência acoplado forneceu registros estáveis e seguros de eletrorretinogramas a partir da córnea comparado aos obtidos com o eletrodo DTL ${ }^{\circledR}$ comercialmente disponível. O protótipo é um instrumento alternativo viável para registro clínico da eletrorretinografia para avaliar a função retiniana, no entanto, análises adicionais são necessárias para validar sua utilidade clínica em pacientes com distúrbios retinianos.

Descritores: Eletrodos; Eletrorretinografia/instrumentação; Retina/fisiologia; Doenças retinianas; Estudos de validação

\section{REFERENCES}

1. Birch DG, Anderson JL. Standardized full-field electroretinography. Normal values and their variation with age. Arch Ophthalmol. 1992;110(11):1571-6.

2. Marmor M, Holder GE, Seeliger MW, Yamamoto S; International Society for Clinical Electrophysiology of Vision. Standard for clinical electroretinography (2004 updated). Doc Ophthalmol. 2004;108(2):107-14.

3. Marmor MF, Hood D, Keating D, Kond M, Seeliger M, Miyake Y; International Society for Clinical Electrophysiology of Vision. Guidelines for basic multifocal electroretinography (mfERG). Doc Ophthalmol. 2003;106(2):105-15.

4. Hood D. Assessing retinal function with the multifocal technique. Prog Retin Eye Res. 2000;19(5):607-46.

5. Yin H, Pardue MT. Performance of the DTL electrode compared to the jet contact lens in clinical testing. Doc Ophthalmol. 2004;108(1):77-86.

6. Lachapelle P, Benoit J, Little JM, Lachapelle B. Recording the oscillatory potentials of the electroretinogram with the DTL electrode. Doc Ophthalmol. 1993;83(2):119-30.

7. Dawson WW, Trick GL, Litzkow CA. Improved electrode for electroretinography. Invest Ophthalmol Vis Sci. 1979;18(9):988-91.

8. Hébert M, Lachapelle P, Dumont M. Reproducibility of electroretinograms recorded with DTL electrodes. Doc Ophthalmol. 1996;91(4):333-42.

9. Esakowitz L, Kriss A., Shawkat F. A comparison of flash electroretinograms recorded from Burian Allen, JET, C-glide, gold foil, DTL and skin electrodes. Eye. 1993;7(Pt 1):169-71.

10. Kuze M, Uji Y. Comparison between Dawson, Trick, and Litzkow electrode and contact lens electrodes used in clinical electroretinography. Jpn J Ophthalmol. 2000;44(4):374-80. 